\title{
Strategic Analysis of Corporate Marketing in Culture Management
}

\author{
Dinko Jukić \\ Trade and Commercial School "Davor Milas" Osijek, Croatia
}

\begin{abstract}
Postmodernism dictates the boundaries of culture that once perceived and imposes new insights. Adding a symbolic meaning to brands expands the understanding of cultural brands. The purpose of this paper is to analyse and discuss the strategic positioning of corporate marketing in segment of cultural management. Insights and reflections derived from corporate marketing and from the brand theory literature are adopted in the paper. Author of the paper analysed three type of cultural segment: school, theatre and museum. The behaviour of employees is very important element in the expression of corporate identity. In this paper, we compare all three segments of culture with Balmer and Aaker's model. We describe a model for managing corporate brands, corporate identity, corporate image and corporate reputation. Author of the paper draws on key literature relating to corporate marketing and marketing in culture. Main goal is to broaden our understanding corporate branding using a model $\mathrm{C}^{2} \mathrm{ITE}, \mathrm{AC}^{4} \mathrm{ID}$ Test and brand personality. Finally, we review corporate identity and image as key factor in building culture management. Ultimately, the culture brand is based on the essence of art, to the desired image that makes the vision of brand, that is, from a consumer perspective, a renaissance individual with a need for cultural brands.
\end{abstract}

\section{Keywords}

Corporate marketing, brand, identity, brand personality, culture management.

\section{Introduction}

For centuries, there are common interdisciplinary and intermediate ties between culture and art. Just remember the Fin de Siècle of European modernism (Jensen, 1994, p. 18) and relation toward the theatre. There are very few common notes about the term of culture and marketing (Meler, 2006, p. 174), especially marketing in museums and theatre. The reason for this comes from the very nature of art: art is not for practical use and is limited to a smaller number of people. Art presents a personal view of society, and the work of art becomes a reflection of such a viewpoint. Culture represents the totality of human accomplishments and artistic expression.

An outcome of art, theatre or museum product is of no use to audience if it does not get in communication with the viewer. The play is an artistic act according to the theory of theatre (Balme, 2011, p. 1). At the same time, the theatrical performance without regard to the viewer is not completed and complete theatrical act. From a production point of view, without a viewer, theatrical performance represents uselessly spent money. In addition, the modern museum represents a place of interpretation of social values and culture. It is evident that the culture of going to the museum and the theatre appears because of creating cultural needs.

Culture as well as any other activity requires an appropriate organization and management in order to achieve that management in culture is not controversial. As in any other production and theatrical production, it produces a product for selling. The same goes for the museum just because the message was transmitted to the employees and the interpretation of the exhibits. However, what is controversial is certainly a myth that culture and marketing cannot go together. 


\section{Culture as a product}

Culture is one of the two or three most complicated words in the language (Williams, 2015, p. 87). Postmodernism dictates the boundaries of culture that once perceived and imposes new insights. Although postmodernism proved to be a problematic and indeterminate concept, particularly from the aspect of the new marketing paradigm (Brown, 1993, pp. 19-34), here we will observe it from a marketing and cultural perspective. Postmodernism in culture leads to the predominance of production over the reproduction, which is also a postmodern feature, because of such understanding everything is becoming cultural.

It is evident that postmodernism leads to the collapse of the communication itself in which everything becomes simulated (Baudrillard, 2017, pp. 121-129). Accepting the theory of simulacrum, society is based on production and image exchange, and consumers have nothing to do with the reality that these images mean. Postmodern marketing is the foundation of such consumer change. Production, reproduction, image, simulation, and brand are no longer a result of the circumstances (Firat \& Venkatesh, 1993, pp. 227-249). Modern society's consumer behaviour is characterized by consumer desires that are created and need not to be based on real needs. The needs are created and transformed into images that become consumer real wishes.

Culture is viewed as a "battlefield" (Eagleton, 2002, pp. 51-87) because they contrast each other with various forms of cultural activity from identity to popular culture (Strinati, 2004, pp. 518). Despite the fact that culture is understood differently, the concept of culture, according to Said (1994, p. 12), implies a "sublime element", and in postmodern society it implies the overall way of life of people (Eagleton, 2002, p. 47). Cultural theorists (Said, 1994, pp. 12-37; Eagleton, 2002, pp. 54-73; Strinati, 2004, pp. 545; Colbert, 2012, pp. 13-37; Williams, 2015, pp. 87-93) cite the dynamics of culture on the one hand, while on the other hand they speak of symbolic experience. The concept of culture is a complex, multidisciplinary construct and cannot include in itself a unique, universal definition. If we accept the metaphor of culture as a battlefield (Eagleton, 2002, pp. 51-87) then culture can be seen as dominant and popular, accepting the fact that popular culture should not be considered less valuable than the opposition of high culture, so called sub culture (Williams, 2015, p. 92).
In this way, the difference between culture and popular culture is wiped out because in postmodernism everything can turn into a reference to popular culture, even the worship of the brand. Brand Cult (Acosta \& Devasagayam, 2010 , p. 168) represents a powerful brandworship identifying with a group of like-minded people. Consumers perception of identity is very important as well as the perception of social belonging to a particular brand, which is particularly pronounced when analysing the relationship between employees and consumer (Homburg, Wieseke \& Hoyer, 2009, pp. 38-54)

This is especially true in management of culture because the needs for artistic values of man are not innate and do not exist as a natural phenomenon. That is why every community in each culture develops and promotes such a need through the education system. The inborn need for the theatre, the connection between man and culture and theatre as the basis of civilization will be seen as a cultural product that depends on theories of corporate marketing (Balmer, 2001a, pp. 1-17).

We cannot see artwork as consumer goods because it is not designed to satisfy consumer desires. Ideas and emotions can be branded (Keller, 2001, pp. 15-19). After all, consumer perceptions and emotions are the key factor in creating an image. The myth of mistrust of culture and marketing, especially in non-profit organizations, represents a tremendous psychological resistance to marketing. This is because the state secured the survival and functioning of the institution. In market-oriented conditions, cultural production relies on social marketing (Lee \& Kotler, 2016, pp. 21-25). Social marketing promotes ideas as opposed to classical marketing that sells the product. That is, exhibitions, performances or visits to museum services, and producers are resellers. Exactly because the need to consume cultural products and services is not natural, it is necessary to systematically encourage and shape it.

\subsection{A prototype of culture}

The term cultural institution occupies a significant place in society. They are a reflection of the cultural identity of every nation. Cultural institutions enable citizens to open themselves to a multicultural aspect and directly represent different cultures (Colbert, 2012, pp. 13-27). It follows from the above that cultural institutions are dichotomous: they depend on production, i.e. 
those performing arts, such as theatrical performances and those that depend on reproduction, i.e. those that perform already existing works such as cinematography or publishing.

The specificity of the cultural product itself is in a paradox. An artist should offer his work, which is a moment of inspiration, while at the same time the consumer needs to adapt to his product. The problem is bigger because the institutions depend on this product (service) on the one hand and on the other hand depend on consumers. On the artistic side, each piece is a prototype because once performed it cannot repeat the same way as a theatre play or opera cannot have the same quality if another orchestra performs. This means that distinguishing products from products in art creates a prototype of a cultural product that is also serially reproduced (Colbert, 2012, pp. 31-37).

The orientation of the organization's mission can be positioned on a continuum from market focus to product focus (Cox, Radbourne \& Tidwell, 1998, pp. 180-187). The production of artwork consists of unique products that are not intended to be reproduced, such as artistic paintings or sculptures in museums. However, reproduction of prototypes, such as books or films, creates prototypes of culture as a product. So every piece of art is a prototype (Colbert, 2012, pp. 13-27), but at the same time the purpose of the prototype is to reproduce in multiple copies, which is specific to replicas in museums or theatrical performances. Figure 1 shows the criterion for distinguishing cultural works from the aspect of cultural organization.

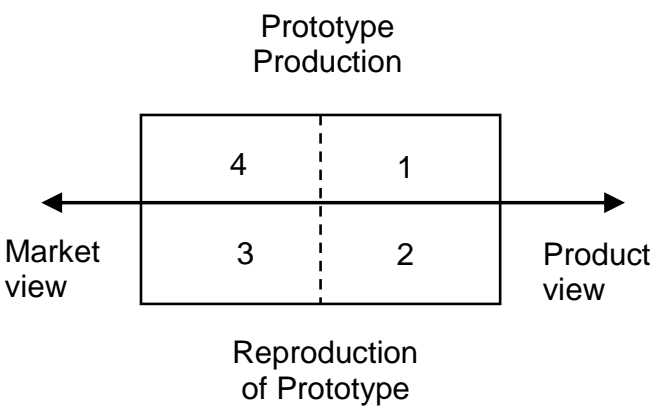

Figure 1 Criteria for cultural prototype Source: Adopted by Colbert, 2012, pp. 7-19

In square 1, organizations are grouped, focusing on creating unique art (cultural) products prototypes. Classical examples are theatres that perform performances or museums that preserve the original cultural goods. Square 2 is a group of corporations that produce the product in multiple copies, and they are the opposite of square 1 because they start from reproduction of a predetermined prototype. These are mostly publishers or directors who also belong to the art sector. Square 3 shows organizations that are focused on the market and there are most cultural industries and distributors there. In square 4, cultural brands are grouped. Such organizations produce unique cultural works that are focused on the market but respect the production of prototypes.

Relying on postmodern postscript (Brown, 2001, p. 118), art and marketing are much closer than implied. At the same time, accepting the theory of simulacrum (Baudrillard, 2017, p. 121129), the society is based on the production and exchange of images, that is, postmodernism emphasizes the influence of symbols on the design of needs. That is to say, in the postmodern marketing paradigm, the consumer becomes an active participant in the repositioning of images and symbolic meanings. In the field of art, where emotions play an important role, the hedonic satisfaction of the consumer experiences from contact with the artwork is a key element (Colbert, 2014, p.564).

\subsection{Cultural brand}

The brand represents a promise that eventually evolves into corporate reputation. By doing so, reputation becomes undoubtedly the most significant asset in modern management. An important strategic decision for each corporation is how to mark the brand (Kotler \& Keller, 2008, p. 296): as a single name, general, or a corporate name. Corporate reputation is the result of continuous action over time and this is the key difference between the brand name and the corporate brand. The corporate brand encompasses a wider spectrum and requires coordination of a number of elements that directly or indirectly affect the ultimate outcome. In addition, a greater number of elements have a reflection on the creation of brand personality (Aaker, 1997, pp. 347-357).

The brand identity is a unique set of associations found in consumer and other stakeholder impressions (Aaker, 1996, p. 27) and is one of the key brand building factors. The cognitive perspective of consumers towards brands starts with the strength and brand association. Brand strength is based on good 
positioning of the brand, i.e. its most important component, consumer associations.

The brand's personality construct is understood as a form of attributing the character of the brand's human character in order to achieve distinctiveness. Such a brand dehumanization construct approaches consumer perceptions, associations and impressions according to brands. The brand's personality is based on the hypothesis that the consumer is perceived by the personification of human traits as shown in Figure 2. The brand's personality is perceived as a multidimensional construct expressed through consumer's emotional attributes and is most often represented through five dimensions: honesty, excitement, ability, refinement and ugliness. Each dimension consists of facets that represent the character of the dimension as illustrated in Figure 2.

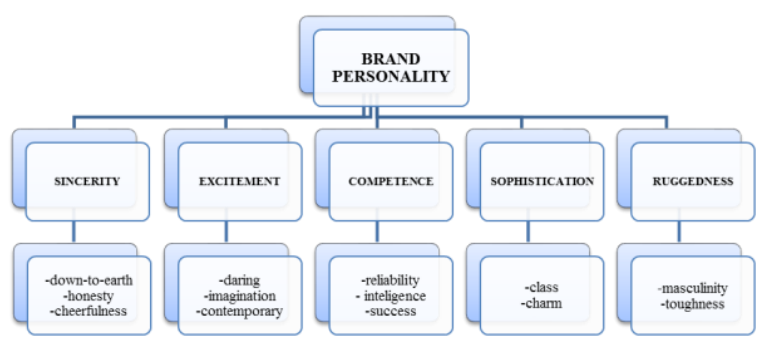

Figure 2 Brand Personality Dimensions Source: Adopted by Aaker, 1997, pp. 347-356

The brand's personality was built according to the theory of anthropomorphization (Epleye, Waytz \& Cacioppo, 2007, pp. 864-886), indicating that brands are changing according to visibility. Personality has proven to be useful for analysing consumer behaviour for brand choice as it reveals how consumers feel about brands. Brand personality (Aaker, 1997, p. 347) is defined as a set of human characteristics associated with a brand. Consumers make brand choices based on the perception they have of themselves.

We distinguish the concept of a cultural brand from the image aspect. Brand image results from the favourability, strength, uniqueness and types of brand associations held by the consumer. All brands are cultural (O'Reilly, 2005, p. 582), but there are different types of cultural brands that we called cultural brands and are divided into three categories: cultrepreneurs, commercial corporations and cultural corporates. The term cultrepreneurs represents well-known artists who have adapted their marketing strategy to promote themselves as cultural icons or art brands. The second group of cultural brands are commercial corporates and they are, from a sociological aspect, a cult brand (Acosta \& Devasagayam, 2010 , p. 168), which over time become icons through mythic creation process or simulation of simulated simulacrums (Baudrillard, 2017, pp. 121-129). Finally, cultural corporations are organizations such as theatres, museums, schools, universities, art galleries and all organizations that incorporate culture in the wider sense of the word. Each type of cultural brand starts with a key segment of an image, i.e. an association, so cultrepreneurs start from creating an icon. Commercial corporate is the starting point of simulation, and cultural corporations are based on the association of culture as illustrated in Figure 3.

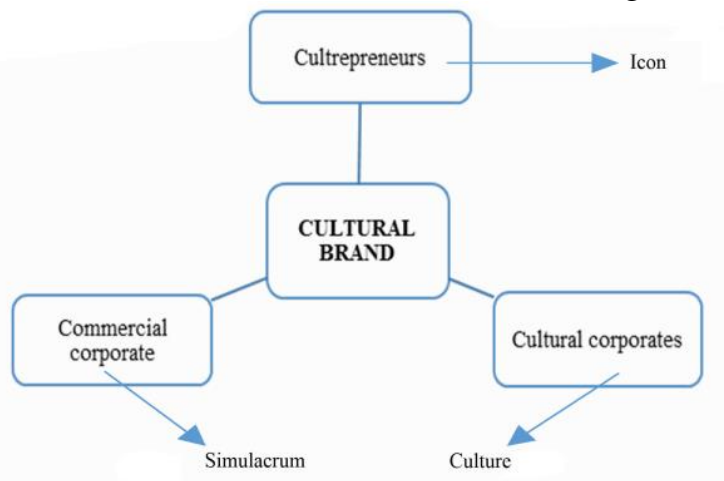

Figure 3 Cultural brand and associations Source: The author

By adding symbolic meaning to brands, the understanding of cultural brands is widening. Brands are not only at the symbolic level of cultural products but also in sociological, especially if we analyse them from the aspect of the brand of gold or the brand attachment construct. The theory of attachment (Steele, 2003, pp. 83-101) starts with the assumption that beliefs and self-confidence feelings are predetermined by the object of self-reliance. Attendance is interpreted as an attachment to the object, as the consumer is viewed from the perspective of the consumer's relationship to marks (Park, Maclnnis \& Priester 2008, p. 4). The attached object becomes associated with consumer selfpromotion, which implies a consumer's perception. To create brand behavioural loyalty is not enough, strong personal attachment is also necessary (Keller, 2001, p. 15). Actual selfcongruence has the strong influence on emotional brand attachment (Malar, Krohmer, Hoyer \& Nyffeggern 2011, pp. 35-52). This effect is even more pronounced when it comes to cultural brands because consumers are involved in the 
prototype of culture especially when it comes to the interpretation of cultural goods in the museum or theatrical performances.

\section{Corporate marketing analysis in culture}

Corporate marketing starts with corporate identity and brand. The increased interest in corporate brand, both in science and marketing, has been occurring in the last twenty years (Balmer, 1995, pp. 24-46; Balmer \& Sonsen, 1999, pp. 69-92; Balmer, 2001a, pp. 248-249; Balmer, 2001b, pp. 11-21; Hatch \& Schultz, 2001, pp. 129-134; Harris \& de Chernatony, 2001, pp. 441-456). The syntagma of corporate brand, which today is known as the marketing doctrine, is not identical to the notion that emerged in the nineties (King, 1991, pp. 43-52).

The corporate brand represents a special form of marking strategy where different segments of management and marketing play a very important role. The corporate brand building most often implies the organizational value of the corporation, the core and the benefit (Urde, 2003, pp. 1017-1040). At the same time, the assumption that the corporate brand will be built in the organization is conditioned by internal and external factors. The corporate brand is a rare entity of marking due to the unique development of the organization (Balmer, 2001a, pp. 248-291). It is an acknowledgment to the corporation that they themselves can contribute to brand development through differentiation, identity, legacy, communication and consumer relationships (Schultz \& Antorini \& Csaba, 2005, pp. 9-20). In order to build a corporate brand, organization must first build a corporate culture that will encompass employee behaviour.

However, since the organization culture is deeply rooted in the employee's perception, it is necessary to develop the brand identity on the cultural reputation, i.e. on the coherence between the brand promise and the performance that employees provide. Trichotomy of a corporate brand is analysed by Keller's methodology of image (Keller, 2001, pp. 15-19; Keller \& Aperia \& Georgson, 2008, pp. 42-87). The first associations of corporate brand images that correlate with Kapferer's brand identity (Kapferer, 2008 , p. 183) relate to employee attributes, benefits, and corporation correlations. Such associations, according to the CBBE model, are called picture of images and they are socially responsible. Table 1 shows the relationships of identity, image, culture, personality and corporate brand.
Table 1 Correlations of corporate brand elements

\begin{tabular}{l|l|l|l|l}
\hline $\begin{array}{c}\text { Corporate } \\
\text { Brand }\end{array}$ & $\begin{array}{l}\text { Corporate } \\
\text { Identity }\end{array}$ & $\begin{array}{c}\text { Corporate } \\
\text { Image }\end{array}$ & $\begin{array}{l}\text { Corporate } \\
\text { Culture }\end{array}$ & $\begin{array}{l}\text { Corporate } \\
\text { Brand } \\
\text { Personality }\end{array}$ \\
\hline $\begin{array}{l}\text { The sum of } \\
\text { identity, } \\
\text { vision and } \\
\text { corporate } \\
\text { image }\end{array}$ & $\begin{array}{l}\text { Brand } \\
\text { features that } \\
\text { represent } \\
\text { corporation }\end{array}$ & $\begin{array}{l}\text { Impressions } \\
\text { that creates } \\
\text { corporate } \\
\text { identity }\end{array}$ & $\begin{array}{l}\text { Employee } \\
\text { and clients } \\
\text { relationship }\end{array}$ & $\begin{array}{l}\text { Brand } \\
\text { values that } \\
\text { are } \\
\text { projected } \\
\text { through } \\
\text { corporate } \\
\text { culture }\end{array}$ \\
\hline
\end{tabular}

Source: The author

The corporate brand concept includes management decisions and corporate culture to unite the three virtues of corporations that we understand in the holistic aspect of all levels of management, communication, and service delivery. The basic difference between a corporate brand and a brand of goods or services begins with managerial-marketing changes. The initiator of the change is no longer just a marketing manager but a complete management, becoming responsibility of all employees at the end. The corporate brand focus encompasses the entire organization, all internal and external factors, unlike the brand focus that entirely depends on consumer perception. The role of corporate identity, image and culture is of crucial importance for the development of corporate marketing (Balmer \& Greyser, 2006, pp. 730741).

The responsibility of non-profit organizations, such as schools, theatres and museums, is based on the amount of services and customer satisfaction. For this reason, the application of strategic marketing planning is necessary to achieve the efficiency of the exchange of services. The benefits of applying strategic marketing in cultural management are numerous: target groups are determined, user needs are defined, financial stability is ensured and quality communication between service providers is ensured as well.

Table 2 shows the characteristics of corporate brand $C^{2}$ ITE model. The model illustrates the characteristics of corporate brand through five key concepts, starting with the culture that encompasses "cultural roots" (Balmer, 2001a: 248-291; Balmer \& Gray, 2003, pp. 972-997), the value of corporate culture, subcultural milieus, regionalism and nationalism. 
Table 2 Model CITE

\begin{tabular}{l|l}
\hline Characteristics & Performance \\
\hline Culture & "cultural roots", subculture, nationality \\
\hline Intricate & $\begin{array}{l}\text { Integrated communication, } \\
\text { multidimensional }\end{array}$ \\
\hline Tangible & visual brand identity, consumer relations \\
\hline Ethereal & style, associations, emotional impressions \\
\hline Commitment & reputation, employee support \\
\hline
\end{tabular}

Source: Balmer, 2001c, p.3

The concept of cultural roots metaphorically embraces elements of heritage, nationality, history, culture, and all forms of corporate culture that imply employee relationships. The remaining characteristics are complemented by the elements of the corporate brand. In order to segment the market of cultural brands, the producer plays the key role, with need to have a clear vision of his performance on the market. Table 3 shows the symptoms of the theatrical prototype that originate from the particularity of the performance itself to the possibility of adjustment. Next, Table 4 and Table 5 show the prototypes of museum adaptation to the market and the role of school in the cultural context.

Table 3 The dimensions of theater in cultural management

\begin{tabular}{|c|c|c|c|c|}
\hline $\begin{array}{l}\text { The } \\
\text { specialty of } \\
\text { the play }\end{array}$ & $\begin{array}{l}\text { The } \\
\text { advantages of } \\
\text { the play }\end{array}$ & $\begin{array}{l}\text { Time } \\
\text { limitations }\end{array}$ & $\begin{array}{l}\text { Category of } \\
\text { the play }\end{array}$ & $\begin{array}{l}\text { Customize of } \\
\text { the play }\end{array}$ \\
\hline 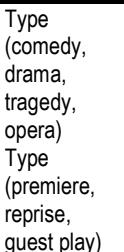 & $\begin{array}{l}\text { Differentiation } \\
\text { (first } \\
\text { performance in } \\
\text { the city, } \\
\text { premiere, new } \\
\text { text) } \\
\text { Cultrepreneurs } \\
\text { (famous actors) }\end{array}$ & $\begin{array}{l}\text { Accompanied } \\
\text { (anniversary } \\
\text { of the death of } \\
\text { a writer, } \\
\text { Christmas } \\
\text { concert, } \\
\text { avant-garde) }\end{array}$ & $\begin{array}{l}\text { Differentiation } \\
\text { (school, } \\
\text { university, } \\
\text { young } \\
\text { audience, } \\
\text { subculture, } \\
\text { middle class) }\end{array}$ & $\begin{array}{l}\text { Advertising } \\
\text { (the most } \\
\text { prized show, } \\
\text { theatre of the } \\
\text { absurd, } \\
\text { national) }\end{array}$ \\
\hline
\end{tabular}

Source: The author

Unlike products, services and art experiences cannot be tried, seen, or tested in the classical sense. Precisely because of the characteristics of intransigence, services have a particularly important role in art because it depends heavily on two factors: user perception and employee motivation. Let us analyse the first factor, the service user. Cultural institutions can offer their cultural brands, prototypes (Colbert, 2012, pp. 1327) by having to "materialize" them through posters, brochures, books, and by that act to create a proto-brand. Proto-brands are the pioneers of today's modern brands (Moore \& Reid, 2008, pp. 419-432) because they marked the goods with the same marks that represented a certain degree of quality and place of creation. Such prototypes included a certain value for consumers and the power of differentiation, and in the cultural segment, they are a semi-tangible service.
Table 4 The dimensions of museums in cultural management

\begin{tabular}{l|l|l|l|l}
\hline $\begin{array}{l}\text { Exposure } \\
\text { specialty }\end{array}$ & $\begin{array}{l}\text { The advantage } \\
\text { of the } \\
\text { exhibition }\end{array}$ & Time limitations & $\begin{array}{l}\text { Exhibition } \\
\text { category }\end{array}$ & $\begin{array}{l}\text { Adaptation of } \\
\text { the exhibition }\end{array}$ \\
\hline $\begin{array}{l}\text { Type } \\
\text { (archaeological, } \\
\text { artistic, technical, } \\
\text { historical, } \\
\text { ethnographic) }\end{array}$ & $\begin{array}{l}\text { Differentiation } \\
\text { (the first type of } \\
\text { museum in the } \\
\text { city, new } \\
\text { exhibits) } \\
\text { National, } \\
\text { regional, city }\end{array}$ & $\begin{array}{l}\text { Engagements } \\
\text { (branding, } \\
\text { anniversary of } \\
\text { death, related to } \\
\text { the project) }\end{array}$ & $\begin{array}{l}\text { Differentiation } \\
\text { (tourist, school, } \\
\text { university, young } \\
\text { audience, sub } \\
\text { culture) }\end{array}$ & $\begin{array}{l}\text { Appropriate } \\
\text { (local, national or } \\
\text { international } \\
\text { exchange, } \\
\text { galleries) } \\
\text { Salons, clubs and } \\
\text { schools }\end{array}$ \\
\hline
\end{tabular}

If, on the one hand, there is a complex art museum or classical theatre, and on the other hand, there is a need for theatres and museums that are not concerned only with classic themes, there is a question of consumer identity. Conflict between modern society, the break between classical culture and popular culture leads to postmodern marketing. Cultural turmoil takes place in three ways: between cultures as evidence of civilization, culture as postmodern and culture as identity. Such differences (Eagleton, 2002, p. 67) between culture and culture (Williams, 2015, p. 92) lead to postmodern marketing dominance. Identity in the postmodern society is a transformation of traditional identity. The accelerated growth of museums and theatres is the answer to the loss of such identity, which is particularly noticed in the evolution of marketing in art as a sub discipline (Colbert, 2017, p. 8).

Table 5 The dimensions of the school in cultural management

\begin{tabular}{l|l|l|l|l}
\hline $\begin{array}{l}\text { The specialty } \\
\text { of the school }\end{array}$ & $\begin{array}{l}\text { The } \\
\text { advantage } \\
\text { of school }\end{array}$ & $\begin{array}{l}\text { Time } \\
\text { limitations }\end{array}$ & $\begin{array}{l}\text { Category of } \\
\text { school }\end{array}$ & $\begin{array}{l}\text { Adjusting the } \\
\text { school }\end{array}$ \\
\hline $\begin{array}{l}\text { Educational } \\
\text { factors } \\
\text { (cognitive, }\end{array}$ & $\begin{array}{l}\text { Creating } \\
\text { needs } \\
\text { (learning, }\end{array}$ & $\begin{array}{l}\text { Attractive } \\
\text { (school culture, } \\
\text { events, } \\
\text { suchophysical } \\
\text { social and } \\
\text { emotional) }\end{array}$ & $\begin{array}{l}\text { guest } \\
\text { performances } \\
\text { excursions, } \\
\text { (galleries, } \\
\text { art and } \\
\text { organized } \\
\text { vocational) }\end{array}$ & $\begin{array}{l}\text { Presentations } \\
\text { (school days, } \\
\text { thematic } \\
\text { workshops, } \\
\text { marking } \\
\text { period) }\end{array}$ \\
& $\begin{array}{l}\text { lerary } \\
\text { debates) }\end{array}$ & & & \\
\hline
\end{tabular}

Source: The author

The museum's role was once the collection of encyclopaedic knowledge, affirmation of identity and consciousness of society, but also as a motive for prestige. The museums have raised the level of culture. The museums have experienced a new way of encoding culture, and together with theatres, they have taken forms of consumer identification. In such an environment, great emphasis is placed on employees who are carriers of cultural services. In essence, the most important management segment in culture is the role of employees (Colbert, 2003, p. 288). It is therefore time to forget the myth of the incompatibility of marketing and culture, as 
cultural goods production is one of the leading industries (Colbert, 2014, p. 563).

The $\mathrm{AC}^{4} \mathrm{ID}$ Test has its origins in earlier models of identity-alignment (Balmer, 2001a, pp. 248-291; Balmer \& Gray, 2003, pp. 972-997). $\mathrm{AC}^{4} \mathrm{ID}$ Test approach can be of assistance to corporate marketing managers in ensuring their corporate brands remain vital and meaningful to the shareholders and stakeholders. Seven identities types comprise the corporate constellation: Actual, Communicated, Conceived, Covenanted, Cultural, Ideal and Desired corporate identity. $\mathrm{AC}^{4} \mathrm{ID}$ Test is a strategic, diagnostic and normative to which brand identities should be calibrated (Balmer, 2012, p. 1067). Cultural management was analysed according to the $\mathrm{AC}^{4} \mathrm{ID}$ Test in Table 6.

Table $6 \mathrm{AC}^{4}$ ID Test of culture brand in cultural management

\begin{tabular}{l|l|l}
\hline Identity type & Culture brand & $\begin{array}{l}\text { Construct cultural } \\
\text { management }\end{array}$ \\
\hline Actual & Art & Corporate identity \\
\hline Communicated & $\begin{array}{l}\text { Reputation, } \\
\text { prestige }\end{array}$ & $\begin{array}{l}\text { Corporate brand } \\
\text { communication }\end{array}$ \\
\hline Conceived & Image & Corporate image \\
\hline Covenanted & Education & Corporate brand \\
\hline Cultural & Employee quality & Corporate culture \\
\hline Ideal & Efficiency & $\begin{array}{l}\text { Corporate brand } \\
\text { strategy }\end{array}$ \\
\hline Desired & Homo universalis & Corporate brand vision \\
\hline
\end{tabular}

Source: The author

The first identity is current and represents a realistic positioning type that includes internal values, employee behaviour and activities. The communicated identity encompasses corporate image, corporate reputation and overall corporate communication. Conceived includes the way the brand sees it. Covenanted embraces the brand in the widest sense, it represents the promise that the brand fulfils. Cultural identity is not the same as the cultural brand already represents the role of employees, their behaviour, beliefs and values. The desired identity includes the management vision and the corporate mission of the organization. Finally, the ideal identity points to the optimal, ideal positioning strategy. From the aspect of the culture brand, it starts from the very essence of art as an educational and entertainment component to the desired one that makes the renaissance individual.

\section{Conclusion}

The demands for artistic values are not innate and do not exist as a natural phenomenon and therefore need to be systematically stimulated. Artwork is not seen as consumer goods because it is not designed to satisfy consumer desires. However, postmodernism in culture leads to the dominance of production reproduction that enables the creation of a cultural brand. Accepting the theory of simulacrum, the society is based on the production and exchange of images (Baudrillard, 2017, pp. 121-129) which are based on the symbolism of the brand. From the aspect of cultural management work of art is a prototype (Colbert, 2012, pp. 13-27), and the purpose of the prototype is to reproduce in order to exist in multiple copies. What is common to all categories is precisely its metaphoricity and personification of the brand (Keller, 2001, pp. 15-19). The responsibility of non-profit organizations such as schools, theatres and museums is based on the scope of services and meeting the needs of users. The features of the corporate brand C2ITE (Balmer \& Gray, 2003, pp. 972-997) reveal the symptoms of the theatre prototype, museum exhibits and the influence of the school as the creator of the need. The museums have experienced a new way of encoding culture and, together with the theatres; they take on the forms of consumer identification presented in the AC4ID Test model that reveals brand vision.

The cultural object (Griswold, 2013, p. 94) is perceived as a symbolic element of the cultural tradition and it is gradually changing over time. By doing so, going to theatre play, picture gallery or museum, makes the symbolic value of a cultural product. Buying such cultural brands is an extension of consumer self-reliance. Consumer culture is characterized by social organization in which the relationship between cultural resources merges with symbolic values in the market. Ultimately, the culture brand is based on the essence of art, to the desired image that makes the vision of brand, that is, from a consumer perspective, a renaissance individual with a need for cultural brands.

Future research should analyse the role of employees in cultural activities. The role of employee is of crucial importance for brand value. (Balmer \& Gray, 2003, p. 979). Corporations with loyal employees, who have the same corporate brand affinity, indicate that the corporation has multiple benefits. The role of employees is one of the most important in the sphere of art because 
employees are in the first contact with consumers. In addition, the correlation between the dimensions of cultural values proposed in this

\section{References}

Aaker, D., A. (1996). Building Strong Brands, New York: Free Press.

Aaker, J. (1997). Dimensions of brand personality, Journal of Marketing Research, 34 (3), 347-357. https://doi.org/10.2307/3151897

Acosta, P. M. \& Devasagayam, R. (2010). Brand Cult: Extending the notion of brand communities. Marketing Management Journal, 20 (1), 165-176.

Balme, B. C. (2011). The Cambridge Introduction to Theatre Studies, Cambridge: Cambridge University Press

Balmer, J.M.T. (1995). Corporate branding and connoisseurship, Journal of General Management, 21 (1), 24-46. https://doi.org/10.1177/030630709502100102

Balmer, J. M.T. (2001a). Corporate identity, corporate branding and corporate marketing, seeing through the fog, European Journal of Marketing, 35 (3/4), 248-291 https://doi.org/10.1108/03090560110694763

Balmer, J. M.T. (2001b). From the Pentagon: a new identity framework, Corporate Reputation Review, 4 (1), 11-21. https://doi.org/10.1057/palgrave.crr.1540129

Balmer, J.M.T. (2001c). The three virtues and seven deadly sins of corporate brand management, Journal of General Management, 27 (1), 1-17. https://doi.org/10.1177/030630700102700101

Balmer, J.M.T. (2012). Strategic corporate brand alignment, European Journal of Marketing, 46 (7/8), 1064-1092. https://doi.org/10.1108/03090561211230205

Balmer, J.M.T \& Soenen, G.B (1999). The Acid Test of Corporate Identity Management ${ }^{\mathrm{TM}}$, Journal of Marketing Management, 15 (1-3), 69-92. https://doi.org/10.1362/026725799784870441

Balmer. J. M. T \& Gray, E. R. (2003). Corporate brands: what are they? What of them?, European Journal of Marketing, 37 (7/8), 972-997. https://doi.org/10.1108/03090560310477627

Balmer, J.M.T \& Greyser S. A. (2006). Corporate marketing: Integrating corporate identity, corporate branding, corporate communications, corporate image and corporate reputation, European Journal of Marketing, 40 (7/8), 730-741. https://doi.org/10.1108/03090560610669964

Baudrillard, J. (2017). Simulacra and Simulation. Michigan: University of Michigan Press

Brown, S. (1993). Postmodern Marketing? European Journal of Marketing, 27 (4), 19-34. https://doi.org/10.1108/03090569310038094

Brown, S. (2001). Art of Science? Fifty Years of Marketing Debate, The Marketing Review, 2 (1), 89-119. https://doi.org/10.1362/1469347012569454

Colbert, F. (2003). Management of the arts. Towse, R. (Eds), In Handbook of Cultural Economics (pp.287300). Northampton: Edward Elgar https://doi.org/10.4337/9781781008003.00043

Colbert, F. (2012). Marketing Culture and the Arts, Montreal: HEC Montreal

Colbert, F. (2014). The Arts Sector: A Marketing Definition, paper, but from the aspect of school management and marketing in art, should be researched. sm

Psychology and Marketing, 31(8), 563-565. https://doi.org/10.1002/mar.20717

Colbert, F. (2017). A Brief History of Arts Marketing Thought in North America, Journal of Arts Management, Law and Society, 47 (3), 167-177.

https://doi.org/10.1080/10632921.2016.1274700

Cox, S. \& Radbourne, J. \& Tidwell, P.M. (1998). Museum Marketing: Implications For Extending the Current Literature, Asia Pacific Advances in Consumer Research, 3, 180-187

Eagleton, T. (2002). The Idea of Culture, Oxford: Blackwell Publishing

Epley, N. Waytz, A, Cacioppo, J.T. (2007). On seeing human: A Three Factor Theory of anthropomorphism. Psychological Review, 114 (4), 864-886. https://doi.org/10.1037/0033-295X.114.4.864

Firat, F. A. \& Venkatesh, A. (1993). Postmodernity: The age of marketing. International Journal of Research in Marketing, 10 (3), 227-249 https://doi.org/10.1016/0167-8116(93)90009-N

Griswold, W. (2008). Cultures and Societies in a Changing World, London: Sage Publications

Hatch, M. J. \& Schultz, M. (2001). Are the Strategic Stars Aligned for Your Corporate Brand?, Harvard Business Review, 79 (2), 129-134

Harris, F. \& de Chernatony L. (2001). Corporate branding and corporate brand performance, European Journal of Marketing, 35 (3-4), 441-456. https://doi.org/10.1108/03090560110382101

Homburg, C. \& Wieseke, J. \& Hoyer, W. D. (2009). Social Identity and the Service-Profit Chain. Journal of Marketing, 73 (2), 38-54. https://doi.org/10.1509/jmkg.73.2.38

Jensen, R. (1994). Marketing Modernism in Fin de Siecle Europe, Ney Jersey: Princeton University Press

Kapferer, J. N. (2008). The New Strategic Brand Management, London: Kogan Page

Keller, K. L. (2001). Building Customer-Based Brand Equity. Marketing Management, 10 (2), 15-19

Keller, K. L, Aperia, T, Georgson, M. (2008). Strategic Brand Management, London: Pearson

King, S. (1991). Brand building in the 1990s, Journal of Consumer Marketing, 8 (4), 43-52. https://doi.org/10.1108/07363769110035144

Kotler, Ph. \& Keller, K. L. (2008). Marketing Management, New York: Prentice Hall

Lee, N. R. \& Kotler, P. (2016). Social Marketing. London: Sage Publications

Malar, L \& Krohmer, H. \& Hoyer, W. D. \& Nyffeggern, B. (2011). Emotional Brand attachment and Brand Personality: The relative Importance of the Actual and the Ideal Self, Journal of Marketing, 35-52. https://doi.org/10.1509/jmkg.75.4.35

Meler, M. (2006). Marketing u kulturi. Osijek: Ekonomski fakultet u Osijeku.

Moore, K. \& Reid, S. (2008). The Birth of Brand: 4000 Years of Branding History, Business History, 50 (4), 419.-432. https://doi.org/10.1080/00076790802106299 
O'Reilly, D. (2005). Cultural Brands/Branding Culture, Journal of Marketing Management, 21 (5/6), 573-588. https://doi.org/10.1362/0267257054307336

Park, W. C. \& Maclnnis, J. D. \& Priester, J. (2008). Brand Atachment: Construct, Consequences and Causes, Hanover: Now Publishers

Said, E.W. (1994). Culture and Imperialism, New York: Vintage Books

Schultz, M, Antorini, Y. M., \& Csaba, F. F. (2005). Corporate Branding: An Evolving Concept, Schultz, M, Antorini,Y, M, \& Csaba, F, F. (Eds), In Corporate branding, Purpose/people/process: Towards the Second Wave of Corporate Branding (pp.9-20). Frederiksberg: Copenhagen Business School Press

\section{$\bowtie$ Correspondence}

\section{Dinko Jukić}

Trade and Commercial School "Davor Milas" Osijek Ivana Gundulića 38, 31000 Osijek, Croatia

E-mail: dinkojukic.phd@gmail.com
Steele, M. (2003). Attachment, actual experience and mental representation, Green, V. (Eds), In Emotional Development in Psychoanalysis, Attachment Theory and Neuroscience (pp.83-101). New York: BrunnerRoutledge

Strinati, D. (2004). An Introduction to Theories of Popular Culture, London: Routledge https://doi.org/10.4324/9780203645161

Urde, M (2003). Core value-based corporate brand building, European Journal of Marketing, 37 (7/8) 1017-1040.

https://doi.org/10.1108/03090560310477645

Williams, R. (2015). Keywords: A Vocabulary of Culture and Society. New York: Oxford University Press 